https://doi.org/10.19195/0137-1150.174.4

Data przesłania artykułu: 10.01.2019

Data akceptacji artykułu: 1.04.2020

\title{
YULIIA HRYSHKO
}

Poltavskyi natsionalnyi pedahohichnyi universytet imeni V. H. Korolenka, Poltava, Ukraina (V. G. Korolenko National Pedagogical University, Poltava, Ukraine)

\section{Стилістичні можливості звукопису в мистецькому дискурсі поетів „витісненого покоління”}

\section{Stylistic possibilities of euphony in artistic discourse by the "replaced generation" poets}

\section{Abstract}

The article deals with the special stylistic language means - euphony that intensifies the acoustic and expressive-emotional background of poetical works. The purpose of the research is to distinguish the main types of euphony in poetical discourse by the writers who formed an exceptional Ukrainian culture phenomenon - the "replaced generation", and to determine the functions of phonetic and stylistic resources in poetical communication. The main research methods are: observation of linguistic phenomena, the continuous sampling method, description, linguistic-stylistic analysis, the contextual method and functional-stylistic method. As research material the author used the poetical works by the poets of the "replaced generation": Hryhorii Chubai, Vasyl Holoborodko, Viktor Kordun, Mykola Vorobiov, Taras Melnychuk, Stanislav Vyshenskyi, Oleh Lysheha, Mykhailo Hryhoriv, and others. The most productive types of phonetic-stylistic resources used by these poets are alliterations (with sonorant consonants, blade spirant consonants, sibilant consonants) and frequent paronomasias.

Keywords: euphony, poetical discourse, poets of the "replaced generation", alliteration, paronomasia 


\title{
Стилистические возможности звукописи
}

\author{
в художественном дискурсе поэтов \\ „отверженного поколения”
}

Резюме

Статья посвящена специфическому стилистическому языковому ресурсу — звукописи, которая интенсифицирует акустический и экспрессивно-эмоциональный фон поэтических произведений. Цель исследования - выделить основные типы звукописи в поэтическом дискурсе писателей „отверженного поколения” и выяснить функции фонетико-стилистических ресурсов в художественной коммуникации. В качестве основных методов исследования использованы следующие методы: метод лингвистического наблюдения, метод сплошной выборки, описательный метод, метод лингвостилистического анализа, контекстуальный метод и функционально-стилистический метод. Материалом исследования стали поэтические произведения писателей „отверженного поколения”: Григория Чубая, Василия Голобородько, Виктора Кордуна, Николая Воробьева, Тараса Мельничука, Станислава Вышенского, Олега Лишеги, Михаила Григорива и др. Наиболее продуктивно эти поэты используют такие фонетико-стилистические ресурсы, как аллитерации (состоящие из сонорных, шипящих и свистящих согласных) и парономазии.

Ключевые слова: звукопись, поэтический дискурс, поэты „отверженного поколения”, аллитерация, парономазия

Українська звукова поезія активно почала розвиватися з початку XVIII ст., коли поетами Києво-Могилянської академії практикувалося написання різних видів фонетично насичених віршів (резонуючі вірші, леонінські вірші, філомелічні вірші, доповняльні вірші, асонансні вірші, епіфоричні вірші тощо).

Відмінна ознака поетичного дискурсу — це фонетична організованість, складниками якої, окрім обов'язкових, канонізованих (у певному літературному середовищі в конкретний історико-літературний період) прийомів поетичної техніки, $є$ цілком інакші за своєю фонетичною природою прийоми - оказіональні (Поливанов, 1963, с. 100), до яких належить індивідуально-авторський звукопис. Акустичним властивостям звуків у контексті поетичних творів присвячена чимала кількість праць сучасних українських дослідників-славістів. Так, засоби творення звукової образності як ознаки ідіостилю українських поетів та літературних напрямів студіювала Марина Кабиш. Функціональне навантаження фоносемантичних зв'язків у поетичному тексті з огляду на авторську інтенційність та індивідуальні настанови митця прокоментувала Ірина Штихно. Теоретичним обгрунтуванням звукопису (зокрема, аналіз доробку Івана Франка) займалася Ольга Настенко. Лінгвостилістичний вимір фонічних засобів у поезії вивчала Олеся Тєлєжкіна. 3 методичної точки зору розглядала звукові ресурси в поезії Тетяна Беценко, запропонувавши алгоритм фоностилістичного аналізу художнього 
тексту. Конотаційні параметри акустико-артикуляційних характеристик звуків описала Людмила Українець. Наприкінці минулого століття можливості фоніки художніх творів комплексно розглянув Ігор Качуровський. Однак звукові мовні одиниці у творчості представників самобутнього явища української культури — поетів „витісненого покоління” — ще не були об’єктом детального вивчення.

Мета статті - виділити основні типи звукопису в поетичному дискурсі митців „витісненого покоління” та з'ясувати функції фонетико-стилістичних ресурсів у художній комунікації.

Феноменальне явище поетів „витісненого покоління” (Андрусяк, 2009, с. 3) - це факт української культури, що сформувався в несприятливий час для українського художнього слова, а саме наприкінці 60-х рр. XX ст., які ознаменували собою припинення періоду „відлиги” для всіх видів мистецтва й початок періоду „закручування гайок” (Андрусяк, 2009, с. 4). У таких нелегких умовах у мовно-культурному просторі сформувалася нова генерація поетів, що відкидала будь-які компроміси з репресивним режимом. Покоління цих поетів частково складають також шістдесятники й поети „Київської школи", які не поділяли тодішні панівні ідеї естетики соцреалізму, а вибудовували своє мистецьке світосприйняття у взаємозв'язках із кращими європейськими поетичними традиціями, орієнтуючись при цьому на загальносвітовий контекст. Представниками кола самобутніх митців є Григорій Чубай, Василь Голобородько, Віктор Кордун, Микола Воробйов, Тарас Мельничук, Станіслав Вишенський, Олег Лишега, Михайло Григорів та ін. Їхні твори й обрано матеріалом нашого дослідження.

\section{Методи дослідження}

Для наукового обгрунтування фактичного матеріалу використано спостереження над мовними явищами та метод суцільної вибірки. Описовий метод та метод лінгвостилістичного аналізу застосовано для об'єктивної характеристики типів звукопису у вербальному дискурсі поетів „витісненого покоління”. Контекстуальний метод дав змогу проаналізувати експресивне забарвлення фонетико-стилістичних ресурсів через текстове оточення. Функціонально-стилістичний метод сприяв виявленню різновидів стилістичних властивостей звукопису.

Літературознавець і письменник Іван Андрусяк підкреслив, що покоління поетів, які прийшли на зміну шістдесятництву, можна назвати „витісненим" не лише через історико-політичні умови становлення їхньої творчості, а й через спільні засади мистецького дискурсу, такі як: 1) відмінність від поетичних надбань шістдесятників; 2) естетична й концептуальна спорідне- 
ність; 3) вплив європейських світоглядно-філософських орієнтирів та європейської модерної поетичної традиції (Андрусяк, 2009, с. 6).

У 60-ті рр. український читач завдяки поезії креативних безкомпромісних поетів розвинув здатність розуміти „нежиттєподібне в мистецтві”, тобто незвичну за формою поезію, в якій знаходила вираження вільна, не скута догмами думка. У цей же час активно почала зростати тенденція до вражаючих форм художньої умовності (Макаров, 1990, с. 5-6), навіть концептуальне мислення почало виражатися у „формі незнаних раніше асоціацій” (поєднувалися традиції та новаторство, виразна символіка і яскрава тропіка, асоціативність і сугестія) (Гризун, 2007, с. 19, 71). У сьогоднішніх реаліях ця умовність поетичного дискурсу постає як органічна й невід'ємна властивість художнього мислення (Макаров, 1990, с. 11), що свідчить про нове розуміння природи художньої творчості (Макаров, 1990, с. 13).

Звукове мовлення є інтерцентричним (спільним) відносно егоцентру (поета) та екзоцентру (читача/слухача). Воно є вираженням деякого суб'єктивного образу (Комлев, 1967, с. 184) і підпадає під визначенння комунікативного знака, запропонованого Юрієм Масловим: „Комунікативний знак - всякий умисно відтворюваний матеріальний факт, розрахований на чиєсь сприйняття й покликаний слугувати засобом передачі інформації про що-небудь, що перебуває поза цим фактом" [власний переклад. - Ю. Г.] (Маслов, 1967, с. 284). Ігор Качуровський підкреслив, що звучання твору (добір певних фонем, їхня частотність, послідовність тощо) „діє на нас через інтелект, себто не опосереднено, а безпосередньо - від душі поета навпростець у душу слухача (або читача, якщо той читає ці вірші не подумки, а вголос)" (Качуровський, 1984, с. 8), оскільки „звуки можуть віддавати всі нюанси людських настроїв” (Качуровський, 1984, с. 160).

У поетичному дискурсі представників „витісненого покоління” домінують такі види звукопису:

1. алітерації й асонанси, використані для звуковідтворення та звуконаслідування;

2. алітерації та асонанси для підсилення емоційно-оцінного впливу на адресата (читача/слухача);

3. парономазії, що інтенсифікують смислове навантаження.

Фонетичні повтори, зокрема алітерації й асонанси, мають найвищий ступінь оказіональності, на відміну від повторів лексичних (які почасти використані суто для підсилення фонетичного повтору), адже залежать від індивідуальних, неусвідомлюваних фонетичних асоціацій у творчому процесі (Поливанов, 1963, с. 108). Тамара Сільман виявила здатність оказіонального співзвуччя типу алітерацій та асонансів нести „незапрограмовану стихію звукової інструментовки" (Сильман, 1974, с. 14).

Функції алітерацій та асонансів у художніх творах обумовлені мистецькими інтенціями письменника і $€$ різноманітними, але в основному вони 
полягають у формуванні специфічної звукової, інтонаційної чи смислової виразності тексту. Ігровий аспект звукових повторів максимально відчутний у разі його насиченості, що свідчить про художній експеримент (Корниенко, 2017, c. 86).

\section{Перша група звукопису}

Перший вид звукопису складають звуконаслідувальні й звуковідтворювальні слова, що виражають „тиск звучання на значення”: оскільки навіть окремі звуки є значущими, то їхні поєднання також мають фонетичну значущість, яка почасти неусвідомлювана, однак входить у значення слова, впливаючи на сприйняття (Журавлев, 1991, с. 29). „Звуки мовлення - не просто кубики, з яких побудовані слова, [...] звуки - живі клітини єдиного організму. 3 них бере коріння сама сутність мови - значення. Воно зовсім не виникає невідомо звідки на рівні слова, його сутність - у звуках мовлення, і глибше - у звуках природи” (Журавлев, 1991, с. 157). Поети „витісненого покоління" найчастіше моделюють звуки живої природи. Наприклад, Василь Голобородько, формуючи звукове тло вірша Запізніле прибуття передовсім свистячими звуками, створює акустичний ефект дзижчання бджоли: Дз-дз - це я собі крильцями допомагаю, / а в Києві уже й до утрені дзвонено (Голобородько, 2005, с. 244). Оригінальними є такі контексти, коли звуконаслідування здійснюється не простим підбором звуків або вигуків, а використанням слів або навіть речень, які своїм акустичним складом і нагадують звукові вияви природи, і мають певний поняттєвий зміст, завдяки лексикалізації звуконаслідування виступаючи як своєрідний різновид персоніфікації (Ковальов, 1973, с. 37). Подібні оказіональні персоніфікації є характерним явищем в українському поетичному дискурсі. Такі зразки знаходимо в творах збірки Сониестояння Віктора Кордуна: На березі пологому / вже тихо, / а тут цзвіркун когось благає: / вернись... вернись... (Кордун, 1992, с. 61); I не шепочуть злякані, а шелестять: / ми тільки вишні, вишні... не чіпайте... (Кордун, 1992, с. 259).

У поезії Вчуся в таборі грати на бандурі Тараса Мельничука найчастотнішими є лабіальні приголосні й сонорний дрижачий [р], однак у кінці твору домінують свистячі приголосні, а завершує твір рядок, змодельований асонансами голосних високого підняття [i], [у]. Можемо простежити стійкий асоціативний зв'язок: звуки імітують гру музичного інструмента, який суголосний із душевними порухами душі ліричного героя: вчуся в таборi / грати на бандурі / бо думаю собі / поки я в таборі / то хай хоч навчуся / грати на бандурі // і вчуся вчуся / а то у мене / нічого не виходить: // струни 3-під пальців / тікаю[йу]ть на Украӥ[йі $]$ ну (Мельничук, 2009, с. 58). Подібне суголосся знаходимо у творчому доробку Станіслава Вишенського, у вірші 
Воля. Колискова маятникові, проте у цій поезії камертоном душевного стану ліричного героя $є$ не музичний інструмент, а маятник годинника. Звуконаслідування увиразнені численними парономазіями та алітераціями: $\boldsymbol{O} \boldsymbol{м} \boldsymbol{p}$-O $\boldsymbol{\boldsymbol { M }}$ б-Ом / ім'я[йа]м / талістю втілення / товщ[ич]ею[йу] стрибків з Руки в Руку / Ом поверхів губів / пучок пальців - / Зоря в зірці тече / Ом - пульс лишасться Світові - / в решті решт / з речі - з и [ич]оповерховими притоками / випуска Передтечу (Вишенський, 2009, с. 184).

\section{Друга група звукопису}

Другу групу звукопису утворюють алітерації й асонанси, що інтенсифікують емоційно-експресивний вплив за рахунок високої частотності/повторюваності тих чи тих звуків. Найпродуктивнішими в цьому виді звукопису $€$ шиплячі, свистячі й сонорні приголосні, що підпорядковують собі акустичний ефект голосних, а також семантично марковані лексеми, як-от у поезії Катерина Василя Голобородька: Поміжс стільців, розкиданих на плош [ич] $i$, / поміжс яблук, розсипаних на снігу / поміжс порожнніх автобусів на вулицях, / іде Катерина / і ніяк не вибереться з цього лабіринту. / На плечах чорні птиці, / чорні птиці печаль / Чорні птиці звили свої гнізда в моїх очах / чорні птиці щц[ич]ебечуть в мойх очах / чорні птиці застять світ своїми крилами (Голобородько, 2009, с. 77). Через накопичення свистячих і шиплячих приголосних та завдяки семантично маркованому повтору чорні nmuці, парономазії на плечах печаль письменник виражає надзвичайно потужний сугестивний імпульс, викликаючи в адресатів стійкі емоції смутку, печалі. Семантично марковані лексеми на позначення кольору, обіграні в контексті алітераціями свистячих, шиплячих (на початку та в середині твору) і сонорних (у кінці твору), використовує Микола Воробйов у вірші Сірий мак зими: Сірий мак зими. / Червоний мак літа. // Вибух світла, / наче кущз[ши]. // На

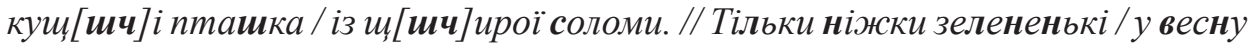
вмочені (Воробйов, 2009, с. 119).

\section{Третя група звукопису}

Третій найпоширеніший тип звукопису в мистецькому дискурсі поетів „витісненого покоління” - парономазія, яка, виступаючи одним із джерел звукопису, грунтується на умисному зближенні слів унаслідок схожості звучання й часткового збігу морфемного складу (Корниенко, 2017, с. 33-34): Ha санскриті життя - гіпотеза, / десь на горах слов'ян хребти: / в колообізідно колодязне, / звідки має відлуння йти (Вишенський, 2009, с. 169). Такою фонетичною „близькозвучністю породжується неповторінсть експресії, що 
відповідно налаштовує мовця емоційно”, адже подібними фонетично змодельованими словами може стимулюватись поява позитивної або ж негативної емоційності (Дудуик, 2005, с. 165): вони свої ночі зігрівали гасом газом / вугіллям дровами / крижаними словами пропонували свої / дрова і газ i гас (Чубай, 1990, с. 11); А світові - голо! / А свтові - босо! // Тиради. / Укази. / Промови. / Доноси. // Таниі. / Ракети. / Паради. / Кастети. // Торговці. / Шпики. / Генерали. / Естети. // Дюжаз-банди. / Футболи. / Космоси. / Наиії. // Боги. / Півбоги. / Парт-ор-гані-за-иії! // Персони. / Парсуни. / Кінозірки. // Голгофи. / Освєнціми. / Соловки. // Дачі. / Собори. / Кремлі. / Мозолі. / Владики на небі / I / на землі (Чубай, 2009, с. 204); вікном широким проти сония / всесвітній розклад і розлад (Мельничук, 2009, с. 63).

Саме звукова близькість і семантичні контакти є основою стилістичних можливостей парономазії: пароніми мають широкі асоціативні зв'язки (Пономарів, 2000, с. 52). Показовоми в цьому плані є вірші Овідій на овиді Віктора Кордуна, Абетка, або Довгий віри Михайла Григоріва, Масаж німбу Станіслава Вишенського: овідій на овиді майже невидимий в білій констанці / зітхає за північ на римську заблукану в сутені повню / таку на вигнанні бездомну й снує із покути / Свропи невтомно / шорстку павутину любовну крізь співи медвяних / волохів тужливі (Кордун, 2009, с. 152); крок ближчий / падіння, / крок археолога, / лінгвіста й художника, / зненацька стятий 3 тятиви / боспорияя (Григорів, 2009, с. 160); Сей світ сам цвіте. Квіти напрямків і манівиів, / як виховання плоду, / як будування бджолиного шляху з добром манівців - / з доторками / до доторкуваних, із спорудженням забуття / з самосісм повернень. / Сей світ - летке й летюче: все, що точить тянсіння - / має вулики, / має незнищенність як фортецю майстрів, / Се я-сам самітний, / се я-втілення, / се $\boldsymbol{я}$ - лінія між зримою й виховуваною / частинами айсберга (Вишенський, 2009, с. 172-173).

Усупереч стереотипам, парономазія не є пріоритетною для створення комічного ефекту: часто вона використовується виключно для акцентування серйозного смислу (Корниенко, 2017, с. 35). Наприклад, Тарас Мельничук та Станіслав Вишенський для прагматичного впливу парономазій та посилення експресивності вводять у контекст творів численні алітерації, адже акустико-артикуляційні властивості звуків, диференційні та інтегральні ознаки сприяють правильному напрямку в декодуванні твору адресатами (Гришко, 2017, с. 89). Так, у поезіях Лист до Богородиці, Журяться журавлі Тараса Мельничука та Реставратор Станіслава Вишенського звукова тканина творів насичена шиплячими звуками, що моделюють стійке асоціативне враження, підкріплене артикуляційно-акустичними характеристиками, які мають потужний вплив на реципієнта навіть за умов внутрішнього промовляння (Журавлев, 1991, с. 127): А я тобі листа напишу, / Щ[ич]о шч[ич]е тоді, Маріє, за совітів / Я був у непідрубаному світі / Пелюсткою підрубаної вишні. / А на тій вишні, Богородице, / На білій вишні / Кривавий цар Микола, 
здається, когось вішав. / А вішав він, либонь, для того, / Щ[шч]об у конюшині не метушилися джммелі... / Вони ж⿻ - заметушились! / Не знали, далебі, / Щ[ич]о ті леш[ич]ата — / Візьмуть нам[ич]адки. / Візьмуть наш[ич] адки, / Щ[ич]об в тих леш[шч]атах / Кісткам трім[шч]ати. / Не знали!.. / Колись я допишу листа, Маріє, / А поки ш[ич]о я жюду Христа: / Зоріс! (Мельничук, 2009, с. 42-43); жсряться журавлі / щ[ич]о рано устали / все одно щ[шч]е не жениться / князь Данило / (щ[шч]е сини його / не повернулися / з Афганістану) // ш[шч]е рано-рано / (ш[шч]е не всі в ранах) (Мельничук, 2009, с. 52); Жовто-жовто цвіте люцерка, / адже справжне - завжди бур'ян: / жовте-жсовте підніжжя церкви, / або злуш:[шч]ене золото бань. // Знати б-тайна вечеря о котрій / і о котрій завершиться світ: / що весна восени непотріб - / я дізнався, дійшовши літ (Вишенський, 2009, с.170).

У вірші Цукрове місто Тараса Мельничука алітерації сонорного дрижачого приголосного [р] на початку строфи породжують негативні асоціативні зв'язки. У середині строфи автор вводить у контекст позитивно маркований для української мовної свідомості плавний боковий [л] (Українець, 2010, с. 43), який поєднуючись із [p], змінює його естетичну модальність на позитивну. На почату строфи [р] - це тюремні розчахнуті брами, у середині строфи - зорі розгорнуть крила: тюремні розчахнуті брами / Замурую ластів 'їними гніздами і аеропортами. / Ластівкам у личе майський вітер засвище / I стане весна - на калину / А земля - на Вкраӥну вища. / Зорі розгорнуть крила / Над полонинами, / Над ув'язненими / $i$ над полоненими (Мельничук, 2009, с. 45).

\section{Висновки}

1. У мистецькому дискурсі поетів „витісненого покоління” найпродуктивнішими формами звукопису є: семантично навантажені парономазії; алітерації, поєднувані з асонансами, що використовуються письменниками для моделювання звуконаслідувань і звуковідтворень, а також для підсилення емоційно-експресивного звучання твору.

2. Засоби звукопису поетів „витісненого покоління” мають потужний прагматичний потенціал і здатні формувати стійкі асоціативні зв'язки (які ототожнюються в мовців із певними позитивними чи негативними явищами навколишньої дійсності).

3. Алітерації в поетичному дискурсі поетів „витісненого покоління” є активнішими й підпорядковують асонанси: для приголосних вирішальними стають диференційні ознаки участі голосу й шуму, місця творення, способу творення та палаталізації, а також інтегральні ознаки акустичного враження (зокрема, свистячі, шиплячі тощо). 


\section{Бібліографія}

Андрусяк, І. М. (2009). Про „Птахів, затиснутих дощами”, або Що існує „У проміжку між травами”. В: Андрусяк, І. М. (ред.), Поети „витісненого покоління”: антологія (с. 3-39). Харків: Ранок [Andrusiak, I. M. (2009). Pro „Ptakhiv, zatysnutykh doshchamy”, abo Shcho isnuie „U promizhku mizh travamy”. V: Andrusiak, I. M. (red.), Poety „vytisnenoho pokolinnia”: antolohiia (s. 3-39). Kharkiv: Ranok].

Вишенський, С. Поезії. (2009). В: Андрусяк, І. М. (ред.), Поети „витісненого покоління”: антологія (с. 168-186). Харків: Ранок [Vyshenskyi, S. Poezii (2009). V: Andrusiak, I. M. (red.), Poety ,vytisnenoho pokolinnia”: antolohiia (s. 168-186). Kharkiv: Ranok].

Воробйов, М. Поезії. (2009). В: Андрусяк, І. М. (ред.), Поети „витісненого покоління”: антологія (с. 114-129). Харків: Ранок [Vorobiov, M. Poezii (2009). V: Andrusiak, I. M. (red.), Poety ,vytisnenoho pokolinnia”: antolohiia (s. 114-129). Kharkiv: Ranok].

Голобородько, В. І. (2005). Летюче віконце. Вибрані поезї. Київ: Укр. письменник [Holoborodko, V. I. Letiuche vikontse. Vybrani poezii. Kyiv: Ukr. pysmennyk].

Григорів, М. (2009). Поезії. В: Андрусяк, І. М. (ред.), Поети „витісненого покоління”: антологія (с. 156-167). Харків: Ранок [Hryhoriv, M. Poezii (2009). V: Andrusiak, I. M. (red.), Poety ,vytisnenoho pokolinnia”: antolohiia (s. 156-167). Kharkiv: Ranok].

Гризун, А. (2007). Поезія концептуальної думки (філософічність сучасної украӥнської поезіi). Суми: Університетська книга [Hryzun, A. (2007). Poeziia kontseptualnoi dumky (filosofichnist suchasnoi ukrainskoi poezii). Sumy: Universytetska knyha].

Гришко, Ю. (2017). Роль диференційних та інтегральних ознак фонем у структурі вокально-консонантних оказіоналізмів. Теоретичні й прикладні проблеми сучасної філологї̈, 6 , c. 87-92 [Hryshko, Yu. (2017). Rol dyferentsiinykh ta intehralnykh oznak fonem u strukturi vokalno-konsonantnykh okazionalizmiv. Teoretychni $i$ prykladni problemyi suchasnoi filolohii, 6, s. 87-92].

Дудик, П. С. (2005). Стилістика мовних одиниць. В: Стилістика украӥнськоїмови (с. 121-288). Київ: Академія [Dudyk, P. S. (2005). Stilistyka movnykh odynyts. V: Stylistyka ukrainskoi movy (s. 121-288). Kyiv: Akademiia].

Журавлев, А. Р. (1991). Звук и смисл. Москва: Просвещение [Zhuravlev, А. Р. (1991). Zvuk i smysl. Moskva: Prosveshchenie].

Качуровський, I. (1984). Фоніка. Мюнхен: Ukrainische freie Universität [Kachurovskyi, I. (1984). Fonika. München: Ukrainische freie Universität].

Ковальов, В. П. (1973). Вимовна експресія художньої прози. Мовознавство, 1, с. 35-41 [Kovalov, V. P. (1973). Vymovna ekspresiia khudozhnoi prozy. Movoznavstvo, 1, s. 35-41].

Колшанский, Г. В. (1967). Семантика слова в логическом аспекте. В: Язык и мышление (с. 187-208). Москва: Наука [Kolshanskiy, G. V. (1967). Semantika slova v logicheskom aspekte. V: Yazyk i myshlenie (s. 187-208). Moskva: Nauka].

Комлев, Н. Г. (1967). Семантическая аспектация язика. В: Язык и мышление (с. 177-187). Москва: Наука [Komlev, N. G. (1967). Semanticheskaya aspektatsiya yazyka. V: Yazyk i myshlenie (s. 177-187). Moskva: Nauka].

Кордун, В. М. (1992). Сонцестояння. Поезї̈. Київ: Дніпро [Kordun, V. М. (1992). Sontsestoiannia. Poezii, Kyiv: Dnipro].

Корниенко, О. А. (2017). Игровая поэтика в литературе. Київ: НПУ ім. М. П. Драгоманова [Korniienko, O. A. (2017). Igrovaya poètika v literature. Kyiv: NPU im. M. P. Drahomanova].

Макаров, А. М. (1990). П'ять етюдів. Підсвідомість $і$ мистеитво: нариси з психології творчості. Київ: Рад. письменник [Makarov, А. М. (1990). Piat etiudiv. Pidsvidomist i mystetstvo: narysy z psykholohii tvorchosti. Kyiv: Rad. pysmennyk]. 
Маслов, Ю. С. (1967). Какие языковые единицы целесообразно считать знаками? В: Язык и мышиление (с. 284-294). Москва: Наука [Maslov, Yu. S. (1967). Kakie yazykovye edinitsy tselesoobrazno schitat znakami? V: Yazyk i myshlenie (s. 284-294). Moskva: Nauka].

Мельничук, Т. Поезії. (2009). В: Андрусяк, І. М. (ред.), Поети „витісненого покоління”: антологія (с. 40-76). Харків: Ранок [Melnychuk, T. Poezii (2009). V: Andrusiak, I. M. (red.), Poety ,,vytisnenoho pokolinnia”: antolohiia (s. 40-76). Kharkiv: Ranok].

Поливанов, Е. Д. (1963). Общий фонетический принцип всякой поэтической техники. Вопросы языкознания, 1, с. 99-112 [Polivanov, Е. D. (1963). Obshchiy foneticheskiy printsip vsyakoy poèticheskoy tekhniki. Voprosy yazykoznaniya, 1, s. 99-112].

Пономарів, О. Д. (2000). Стилістика сучасної украӥнської мови. Тернопіль: Навчальна кгига - Богдан [Ponomariv, O. D. (2000). Stylistyka suchasnoi ukrainskoi movy. Ternopil: Navchalna knyha — Bohdan].

Сильман, Т. И. (1974). Заметки о лирике (мисль - образ - эмоция - звук). Филологические науки, 5, с. 13-24 [Silman, T. I. (1974). Zametki o lirike (mysl — obraz — èmotsiya — zvuk), Filologicheskie nauki, 5, s. 13-24].

Українець, Л. Ф. (2010). Конотація приголосних [л] та [л] в українській заумі. В: Проблеми соціолінгвістики, фоностилістики, граматики, журналістики та методики навчання української мови (с. 40-44). Полтава: ПНПУ імені В. Г. Короленка [Ukrainets, L. F. (2010). Konotatsiia pryholosnykh [1] ta [1'] v ukrainskii zaumi. V: Problemy sotsiolinhvistyky, fonostylistyky, hramatyky, zhurnalistyky ta metodyky navchannia ukrainskoi movy (s. 40-44). Poltava: PNPU imeni V. H. Korolenka].

Чубай, Г. (1990). Говорити, мовчати і говорити знову. Вірші. Київ: Молодь [Chubai, Н. (1990). Hovoryty, movchaty i hovoryty znovu. Virshi. Kyiv: Molod].

Чубай, Г. Поезії. (2009). В: Андрусяк, І. М. (ред.), Поети „витісненого покоління”: антологія (с. 198-229). Харків: Ранок [Chubai, H. Poezii (2009). V: Andrusiak, I. M. (red.), Poety „vytisnenoho pokolinnia”: antolohiia (s. 198-229). Kharkiv: Ranok]. 